\title{
Sources and transports of organochlorine pesticides in the Nanshan underground river, China
}

\author{
Md. Jahangir Alam • Yuan Daoxian • \\ Yong Jun Jiang $\cdot$ Sun Yuchuan $\cdot$ Li Yong $\cdot$ \\ Xu Xin
}

Received: 21 December 2012/ Accepted: 4 November 2013/Published online: 27 November 2013

(C) The Author(s) 2013. This article is published with open access at Springerlink.com

\begin{abstract}
Karst areas have much higher ecological vulnerability and are prone to be contaminated. Organochlorine pesticides (OCPs) were detected in waters and sediment from the two sites of the karst Nanshan underground river system, China, to understand the sources and transport of OCPs in the underground river systems. Obviously, seasonal variations were found both in the waters and the sediments. Detected OCPs ranged from 61 to $936 \mathrm{ng} \mathrm{L}^{-1}$ in the groundwaters and 51-3,842.0 $\mathrm{ng} \mathrm{g}^{-1}$ in the underground sediments, respectively. OCPs in groundwaters were mixture of younger and older residues from commercial sources. The maximum OCPs in the sediments of the underground river were historically older residues from commercial sources. The sources of OCPs in the waters and sediments of the underground river indicated that the surface systems play an important role in OCPs transport and pollution in the underground river. Karst features were liable for the transport behavior.
\end{abstract}

Keywords OCPs $\cdot$ Karst - Underground river system $\cdot$ Sources $\cdot$ Transport

\section{Introduction}

Organochlorine pesticides (OCPs), organic materials with higher bioaccumulation, toxicity, volatility, and long-range atmospheric transport can cause environmental damage,

Md. J. Alam $(\bowtie) \cdot$ Y. Daoxian · Y. J. Jiang · S. Yuchuan . L. Yong $\cdot$ X. Xin

School of Geographical Sciences, Institute of Karst Environment and Rock Desertification Rehabilitation, Southwest University, Beibei, 400715 Chongqing, People's Republic of China e-mail: mira61031@yahoo.com; jiangjyj@swu.edu.cn and affect human health (Mukherjee and Gopal 2002; Nakata et al. 2002). As for examples, OCPs affect the food chain and play roles in nervous excitement, tremors, convulsions, or death. Pesticide exposure ranges from simple irritation of the skin and eyes to more severe effects such as the nervous system, mimicking hormones causing reproductive problems and also causing cancer (Vidal et al. 2000; Cao et al. 2010). For these reasons, the USEPA (2000), enlisted some of OCPs as health hazards in the Stockholm Convention. OCPs were the most widely used pesticides around the world before the 1970s; however, some OCPs are still being produced (Wang et al. 2008a, b, c). Although the uses of OCPs were banned about three decades ago, the elevated concentrations of OCPs residues were still observed in the environments due to their persistency (Meijer et al. 2003). OCPs released in the tropical and subtropical environments could be dispersed through air and water and tend to be redistributed on a global scale Tanabe (1991). The source, transport and fate of OCPs in natural environments have been studied extensively (Tang et al. 2008; Wang et al. 2008a, b; Hu et al. 2009; Jiang et al. 2009a; Kihampa et al. 2010; Zhang et al. 2011). As for example, (Luo et al. 2004) identified the OCP levels in the waters of rivers with concentrations. Anasco et al. (2010) reported that the fresh waters in some rivers are affected by paddy effluents. Galanopoulou et al. (2005) reported higher values of DDTs in sediments influenced from the industrial and urban wastes. (Klánová et al. 2008) reported on OCPs in the soils and sediments from James Ross Island, Antarctica, in which the contamination occurred through long-range atmospheric transport from Africa, South America, and Australia. Jiang et al. (2009a); Muhayimana et al. (2009) and Wang et al. (2011) reported the sources and transport in agricultural soils using ratios of $\alpha / \gamma \mathrm{HCH}, \alpha / \beta \mathrm{HCH}, \alpha / \beta$ endosulfans, cischlordane/trans-chlordane, and DDT/(DDD + DDE). 
Karst groundwater is the drinking water supply for about one-quarter of the population on the earth (Jiang et al. 2009a, b). Karst groundwater systems are particularly prone to contaminations because of their unique hydrogeological characteristics. Due to the formation and development of rocky desertification, the karst system often has little or no soil cover, which leads to poor filtration, poor pre-purification and rapid infiltration (He et al. 2010; Liu et al. 2010). In addition, flow in a karst system has often been conduitdominated and the residence time is usually short, which further limits its ability for self-purification as well as for microorganisms to die off. Furthermore, large numbers of interconnected fissures can make pollutions spread quickly and widely in a karst system (LeGrand 1984; Prohic 1989; Ford 1993). Muhayimana et al. (2009) and Wang et al. (2011) analyzed OCPs in soils in a karst area while Ekmecki (2005) found pollution from OCPs in karst springs waters. Beside these researches of OCPs, nutrient transports have been reported extensively. As for example, groundwater leaching of nutrients from the soils, which is especially evident in areas dominated by agriculture (Zhu et al. 2008; Gao et al. 2009). Nitrogen percolation occurs easily into the groundwater through soil flow with rain water (Naik et al. 2008; Gao et al. 2012). In addition, a field plot experiment was conducted on two types of paddy soils in the Taihu Lake area of China to assess phosphorus losses by runoff and drainage flow from paddy soils (Zhang et al. 2005). Hu et al. (2011) reported contamination from OCPs in the karst underground rivers in Nanshan in Southwest China. This study reported the sources of $\mathrm{HCH}$ and DDTs without other OCPs in the waters of an underground river. For future improvements of drinking water quality in the underground river, it is necessary to know the levels, sources, and transport of OCPs both in the underground river and in the concerned surface watershed.

Therefore, in this study, the focus is on the Nanshan underground river, a karst groundwater system in southwest China, to investigate the contamination level and distribution in the surface water, groundwater and sediments, and efforts to identify the sources and transport pathway of OCPs. This study expects a potential role of a karst area as the pollution in the underground system because potential and actual sources of pollution to groundwater in karst areas are a common concern throughout the world (Bohlke 2002).

\section{Materials and methods}

\section{Study area}

The Laolongdong Underground River System (LURS) area is located at the center of Chongqing municipality,
Southwest China (Fig. 1). The underground drainage area of the system is approximately $12.6 \mathrm{~km}^{2}$. The elevation of LURS is between 350 and $685 \mathrm{~m}$ above average sea level. The climate is primarily subtropical monsoonal with a mean annual precipitation of $1,100 \mathrm{~mm}$ and a mean air temperature of $18.7^{\circ} \mathrm{C}$. The monsoonal climate results in a rainy season from May to October and a dry season from November to April. The population of the Nanshan karst valley is over 50,000 and is associated with rapid urbanization, apart from farming. Residential areas that are concentrated in an internal trough valley produce various effluents, which are discharged into an artificial channel, which flows southward to join the Laolongdong Underground River, then into a tributary of the Yangzi River in Chongqing. There are no sewage treatment plants in the drainage basin. Only a small portion of wastewater from the town and plant discharge to a sewage channel at the surface; most wastewater is discharged directly into the surface water, thus seriously threatening groundwater quality (Guo et al. 2010). The outlet of the Laolongdong underground river is a tourist spot where many people enjoy boating (Lan et al. 2013). Even worse, some sinkholes are used to discharge wastewater residues. By the end of the 1990s, surface ecosystems of the karst valley had been disturbed by human activities and local groundwater has been deteriorating for many years.

\section{Geology and hydrogeology}

It is a transitional zone where the Nanwenquan anticline in the longitudinal structural system turns to the Tongluoxia anticline in NE-SW structural system. The outcrops are principally carbonated rocks (limestone), with Triassic strata being widespread. The strata of the anticlinal axis are carbonate rocks of the Lower Triassic Chialingchiang Formation $\left(\mathrm{T}_{1} j\right)$, with limestone being a major lithology, whereas anticlinal wings are carbonate rocks of the Middle Triassic Leikoupo Formation $\left(\mathrm{T}_{2} l\right)$ and sandstones of the Upper Triassic Xujiahe Formation $\left(\mathrm{T}_{3} x j\right)$. Yellow-green calcareous clay rocks of the Lower Leikoupo $\left(\mathrm{T}_{2} l\right)$ overlie the Chialingchiang Group $\left(\mathrm{T}_{1} j\right)$. No sulfate evaporites (gypsum and anhydrite) are exposed in the study area. Due to the banded distribution of carbonate rocks and the presence of relatively impermeable sandstone, the two wings combined with a vertical patulous cranny, which was well developed in the anticlinal core, basic conditions exist for a formation of a karst trough valley and the development of a karst groundwater system. Precipitation is the major recharge source of the groundwater that ensures abundant groundwater resources. The Laolongdong underground river originates from the core of the karst trough valley and flows along anticlinal axis [Lower Triassic Chialingchiang formation $\left.\left(\mathrm{T}_{1 j} j\right)\right]$ in a NE-SW direction with a total length of $6 \mathrm{~km}$. 
Fig. 1 Locations, land use, hydrological map, and distribution of samples

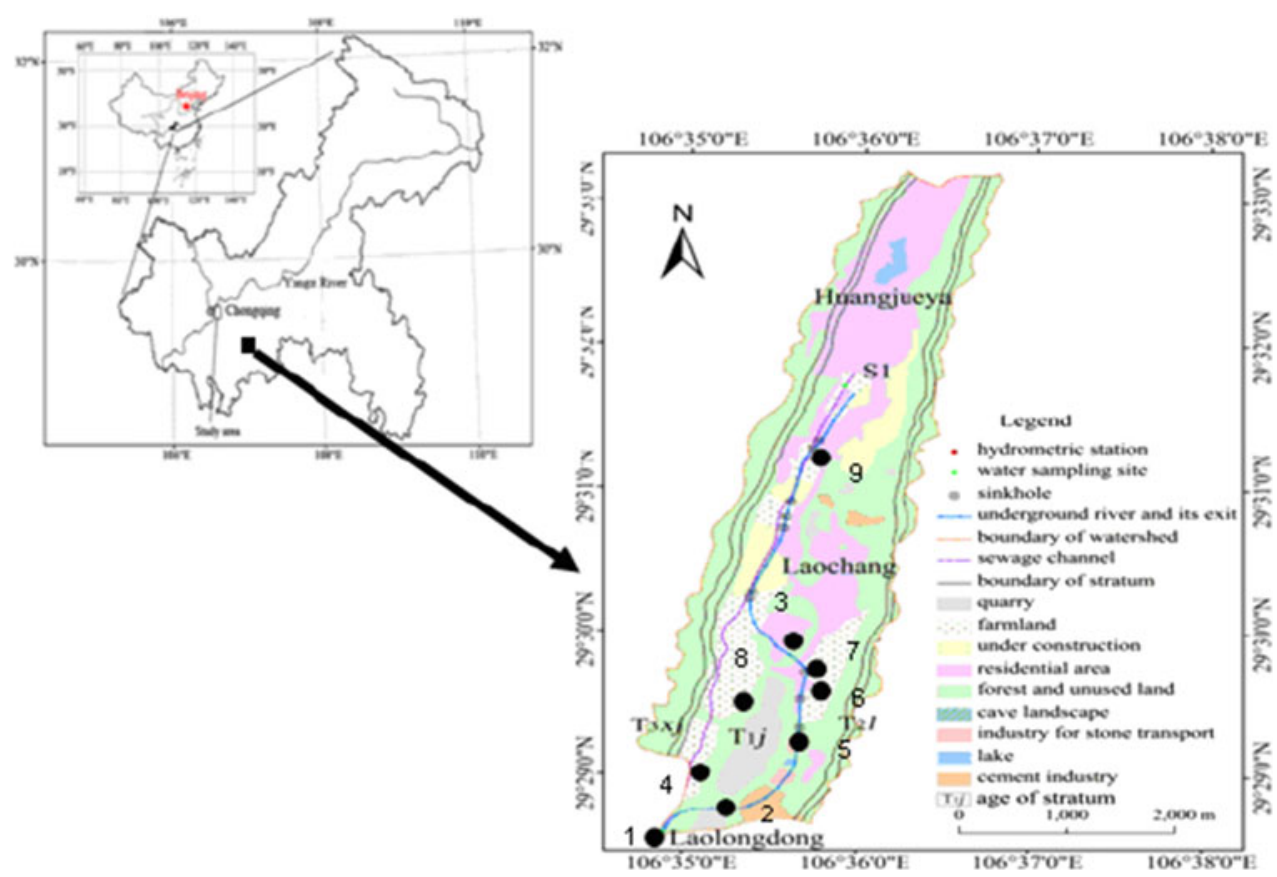

Water samplings in underground niver: 1-UG1, 2-UG2, Sedimerts sampling inunderground river: 1SeUG 1, 2-SeUG2, Water samplings in famlands : 5-FD, 7-FU, 8-F2, 4, 9-Sewch/N sewch, Water samplings in sinkholes: 6 -Shw, 3 S eww, Water samplines in Well: 5-Well. Sediments sanplings in famlands: S-SeFD, 7SeFU, 4SeFL, 9-Sesewch, famland sampling in soils: S-SFD, 7SFU, 8-SFL, 9Ssewch, Water sampling in sinkhole type groundwater. 3-UG3, S ediment sampling inunderground type around water: 3-UG3

Vegetation, soil and land use pattern

A mixture of subtropical evergreen broadleaf needle forests is dominant, including masson pine, fir, cedar, camphor, and ficus virens. The dominant types of soils are mainly limestone soils and yellow earth derived from carbonate rocks and sandstones, respectively. There are four land use categories (Fig. 1): land use for residential construction with an area of $4.5 \mathrm{~km}, 2.5 \mathrm{~km}$ for factories, $2 \mathrm{~km}$ for agriculture, $3 \mathrm{~km}$ of forest and unused land, respectively. Residential areas are built in the center of the northern trough or on either side of the roads. Industries are mainly cement and quarry plants centered among relict mountains along the valley whereas farmlands are scattered around the bottom of the valley (Fig. 1). Underground rivers and springs used to be the only one major source of water supply for the residents.

\section{Samples}

Water samples were collected monthly in individual $1 \mathrm{~L}$ cleaned glass bottle between 2011 and 2012 from the underground river and its surface system (Fig. 1). Farmland waters and underground waters were collected from $10 \mathrm{~cm}$ vertically in the upper layer; $100 \mathrm{~g}$ of sediment samples was collected in plastic bags from the underground river and surface system; $500 \mathrm{~g}$ of soil sample was collected in plastic bags from the surface system. Sediments and soil samples were collected vertically within $5 \mathrm{~cm}$. Collected water samples were preserved in a freezer at $-20{ }^{\circ} \mathrm{C}$ until analysis. After 2 months, water samples were filtered with Whatman GF/F $(0.45 \mu \mathrm{m}$ effective pore) pre-combusted at $450{ }^{\circ} \mathrm{C}$ for $5 \mathrm{~h}$. Surrogate standards $(2 \mu \mathrm{L})$ were added into water samples after the filtration. The filtered water was then passed through solid phase extractor (SPE-DEX controller 4700/4790, Horizon Technology). Soil and sediment samples were air dried before analysis for 2-3 months in a secure place in our school laboratory.

\section{Chemicals}

OCPs standards ( $o, p^{\prime}$-DDT, $p, p^{\prime}$-DDT, $o, p^{\prime}$-DDD, $p, p^{\prime}$-DDD, $o, p^{\prime}$-DDE, $p, p^{\prime}$-DDE, $\alpha-\mathrm{HCH}, \beta-\mathrm{HCH}, \gamma-\mathrm{HCH}, \delta-\mathrm{HCH}, \varepsilon-$ $\mathrm{HCH}$, aldrin, dieldrin, endrin, $\alpha$ endosulfan, $\beta$ endosulfan, Isodrin, Mirex, heptachlor, heptachlor epoxide and methoxychlor, trans-chlordane, cis-chlordane) in a mixture were obtained from Dr. Ehrenstorfer, Germany. Mixed surrogate standard of OCPs 2,4,5,6-tetrachloro-m-xylene (TCMX) and deca chloro bi phenyls (PCB 209), internal standard poly chlorinated nitro benzene $(\mathrm{PCNB})$ in a solution were purchased from Supelco, USA. Silica gel (80-100-mesh) and neutral alumina (100-200-mesh) were extracted with dichloromethane for $72 \mathrm{~h}$ by using an extractor. Upon drying under room temperature conditions, silica gel and alumina were baked at 180 and $250{ }^{\circ} \mathrm{C}$ for $12 \mathrm{~h}$, respectively. Sodium sulfate was baked at $550{ }^{\circ} \mathrm{C}$ for $8 \mathrm{~h}$ and stored in sealed containers (Luo et al. 2004). 
Analytical procedure

About $10 \mathrm{~g}$ soil and sediment dried samples were kept in a cleaned filter paper (for $72 \mathrm{~h}$ ) and every sample including water samples were spiked with the surrogate standards and extracted for $24 \mathrm{~h}$ with dichloromethane. Activated $\mathrm{Cu}$ was added for desulphurization. The extract for each sample was concentrated and solvent-exchanged to hexane, and further reduced to approximately $1 \mathrm{~mL}$ under vacuum rotary evaporator. Concentrated extracts were fractionated with a 1:2 alumina: silica gel glass column and $15 \mathrm{~mL} n$ - hexane, $70 \mathrm{~mL} \mathrm{3:7} \mathrm{di} \mathrm{chloro} \mathrm{methane:} n$-hexane, successively. It was finally concentrated to $0.2 \mathrm{~mL}$. The extracts of water samples were dried by anhydrous sodium sulfate and concentrated to $0.2 \mathrm{~mL}$ with a gentle stream of purified nitrogen. Known quantities of internal standard were added to the sample prior to instrumental analysis.

Analysis

OCPs were measured using gas chromatograph (GC) (Agilent 7890A) equipped with a micro electron capture detector

Table 1 Concentrations, variations, and mean of OCPs in the different samples in the underground and surface system

\begin{tabular}{|c|c|c|c|c|c|c|c|}
\hline \multirow[t]{2}{*}{ OCPs } & \multicolumn{2}{|c|}{ Underground river system } & \multicolumn{3}{|l|}{ Farmlands } & \multicolumn{2}{|c|}{ Sinkholes and well } \\
\hline & $\begin{array}{l}\text { Waters } \\
\left(\text { ng L L }^{-1}\right)^{\mathrm{a}}\end{array}$ & $\begin{array}{l}\text { Sediments } \\
\left(\text { ng g }^{-1}\right)^{\mathrm{b}}\end{array}$ & $\begin{array}{l}\text { Waters } \\
\left(\text { ng L L }^{-1}\right)^{\mathrm{c}}\end{array}$ & $\begin{array}{l}\text { Sediments } \\
\left(\mathrm{ng} \mathrm{g}^{-1}\right)^{\mathrm{d}}\end{array}$ & $\begin{array}{l}\text { Soils } \\
\left(\text { ng g }^{-1}\right)^{\mathrm{e}}\end{array}$ & $\begin{array}{l}\text { Waters } \\
\left(\text { ng L L }^{-1}\right)^{\mathrm{a}}\end{array}$ & $\begin{array}{l}\text { Sediments } \\
\left(\text { ng g }^{-1}\right)^{\mathrm{f}}\end{array}$ \\
\hline$\alpha \mathrm{HCH}$ & $0.6-58.2$ & ND-0.9 & $2.9-818.3$ & $0.1-136.7$ & $0.2-0.9$ & $1.2-739.0$ & $0.3-2.9$ \\
\hline$\beta \mathrm{HCH}$ & $0.4-4.9$ & ND-20.8 & $0.1-37.9$ & $0.1-159.6$ & $0.5-1.4$ & $0.5-264.0$ & $0.9-7.6$ \\
\hline$\gamma \mathrm{HCH}$ & $0.3-44.4$ & $0.1-4.6$ & $0.5-40.6$ & ND-21.6 & $0.2-3.3$ & $0.7-3.5$ & $0.5-13.4$ \\
\hline$\delta \mathrm{HCH}$ & $0.9-5.9$ & ND-62.0 & $0.4-155.3$ & $0.3-277.4$ & $0.3-2.6$ & $1.4-530.0$ & $0.9-30.9$ \\
\hline$\varepsilon \mathrm{HCH}$ & ND-2.2 & ND-62.0 & ND-139.3 & $0.4-277.4$ & $0.2-49.1$ & ND-444.0 & $0.9-30.9$ \\
\hline Heptachlor & $0.1-14.1$ & ND-6.0 & $0.5-58.0$ & $0.1-117.5$ & $0.1-0.6$ & $0.2-65.0$ & $0.2-0.5$ \\
\hline Heptachlor epoxide & $0.1-3.1$ & ND-3415.0 & $0.3-36.4$ & ND-670.2 & ND-0.9 & ND-533.9 & ND-0.3 \\
\hline Aldrin & $2.3-96.1$ & ND-1.3 & $2.1-1173.0$ & ND-142.0 & $0.1-0.2$ & $1.1-926.6$ & $0.2-0.7$ \\
\hline Dieldrin & ND-6.6 & ND-5.9 & $0.4-59.7$ & $0.2-136.3$ & $1.4-48.2$ & ND-56.5 & $6.8-121.5$ \\
\hline Endrin & $0.2-6.8$ & ND-1.2 & $0.7-11.3$ & ND-1.4 & ND-0.9 & $0.5-153.0$ & $1.3-3.9$ \\
\hline$\alpha$ endosulfan & $0.5-14.4$ & ND-21.0 & $0.3-188.2$ & ND-13.1 & $0.1-0.3$ & ND-554.0 & $0.3-2.5$ \\
\hline$\beta$ endosulfan & $0.1-7.8$ & ND-1.2 & $0.6-23.7$ & ND-1.3 & ND-2.5 & ND-59.0 & $0.9-1.3$ \\
\hline$o, p^{\prime}-\mathrm{DDT}$ & ND-15.5 & ND-14.9 & ND-27.5 & ND-245.7 & $0.1-1325.0$ & ND-8.6 & $0.3-6.6$ \\
\hline$p, p^{\prime}-\mathrm{DDT}$ & ND-8.8 & ND-61.3 & $0.9-25.7$ & ND-1.6 & $0.5-3093$ & ND-249.0 & $4.2-6.7$ \\
\hline$o, p^{\prime}-\mathrm{DDE}$ & $0.3-42.2$ & ND-5.6 & $0.3-133.6$ & ND-5643.3 & $0.1-8.0$ & $0.3-271.6$ & ND-9.7 \\
\hline$p, p^{\prime}-\mathrm{DDE}$ & $0.3-19.3$ & $0.1-215.9$ & $2.2-63.6$ & ND-297.5 & $0.1-606.4$ & ND-185.8 & $2.7-4.8$ \\
\hline$o, p^{\prime}-\mathrm{DDD}$ & ND-3.2 & $0.1-1.7$ & $0.4-36.3$ & ND-1.9 & $0.2-298.1$ & $0.1-116.8$ & $0.9-31.6$ \\
\hline$p, p^{\prime}-\mathrm{DDD}$ & ND-5.9 & $0.1-1.2$ & $0.6-9.1$ & ND-7.9 & $0.4-669.5$ & ND-16.3 & $0.8-54.1$ \\
\hline Isodrin & $0.2-4.2$ & ND-22.3 & $0.5-5.92$ & ND-551.5 & $0.1-1.4$ & $0.1-1240.0$ & $0.2-1.9$ \\
\hline Methoxychlor & ND-10.6 & ND-317.8 & ND-10.9 & ND-377.2 & $1.9-49.4$ & ND-991.0 & $0.8-114.9$ \\
\hline Mirex & ND-ND & ND-3.9 & ND-1.4 & ND-2.9 & ND-13.0 & ND-3.2 & ND-18.2 \\
\hline Oxychlordane & ND-848.0 & ND-1621.0 & ND-1213.0 & ND-2219.0 & ND-193.7 & ND-860.0 & $350.0-1383.0$ \\
\hline Trans-chlordane & ND-49.2 & ND-0.7 & $0.8-343.5$ & ND-10.8 & $0.2-2.3$ & ND-284.0 & $1.3-4.2$ \\
\hline Cis-chlordane & $0.9-41.4$ & ND-19.3 & $0.5-1144.0$ & ND-2.1 & $\mathrm{ND}-0.2$ & ND-432.0 & $0.1-0.5$ \\
\hline$\Sigma \mathrm{OCPs}$ & $61.0-936.0$ & $51.0-3842.0$ & $31.0-5639.0$ & $11.0-3469.0$ & $99.0-6181.0$ & $39.0-3492.0$ & $420.0-1709.0$ \\
\hline Mean & 198 & 819 & & & & & \\
\hline Max \% OCPs on surface & 10 & 33 & & & & & \\
\hline$\Sigma \mathrm{HCH}$ & $7.0-93.0$ & $0.1-148.5$ & $7.0-1218.0$ & $3.0-873.0$ & $3.0-53.0$ & $8.0-1523.0$ & $3.5-68.0$ \\
\hline$\Sigma$ DDT & $1.0-47.0$ & $0.8-219.9$ & $5.0-144.0$ & $0.1-570.6$ & $2.0-6000.0$ & $2.0-419.0$ & $21.1-93.8$ \\
\hline
\end{tabular}

${ }^{a}$ September, October, December, January, February, March, April, May

b September, October, December, January, March, May

c September, December, January, February, March, April, May

d September, October, December, April

e September, February

${ }^{\mathrm{f}}$ December, January, February 
( $\mu$-ECD) and an HP-5 MS silica fused capillary column $(30 \mathrm{~m} \times 0.32 \mathrm{~mm}$; film thickness $0.25 \mu \mathrm{m})$. Additional details of the chromatographic and spectrometric conditions are provided elsewhere (Mai et al. 2002). Quantification was performed using the internal calibration method based on five-point calibration curve for individual component.

For each sampling period, two glass bottles of de-ionized (cleaned) water were carried on board and exposed to the ambient environment during the course of field operation. This water was brought back to the laboratory and treated as a field blank. Field blanks were filtered and extracted in the same procedure as the field samples. For each batch of field samples, a procedural blank (solvent with clean GF/F filters) and a spiked blank (25 standard OCPs spiked into solvent with clean GF/F filters) have been taken. The field blank and procedural blank samples contained undetectable amounts of target analyses. The reported results were surrogate corrected. Recoveries were $75-115 \%$ for OCPs of the certified values. For OCPs with a sample size of $1 \mathrm{~L}$, the detection limit ranged from 0.09 to $0.25 \mathrm{ng} / \mathrm{L}$.

\section{Results and discussion}

Levels of OCPs for the waters and sediments in the underground river system

The mean concentration of $\Sigma$ OCPs is $198 \mathrm{ng} \mathrm{L}^{-1}$ in waters. The mean content of $\Sigma$ OCPs in sediments of the underground river is $819 \mathrm{ng} \mathrm{g}^{-1}$ (Table 1). The level of OCPs in sediments is four times higher than that of waters. According to the report of (Luo et al. 2004), the water of the underground river is polluted.

Seasonal variations of OCPs in different samples in the underground river and surface systems

Seasonal variations of OCPs in waters, sediments, and soils are shown in Table 1. The concentrations of $\Sigma$ OCPs in underground river waters ranged from $61 \mathrm{ng} \mathrm{L}^{-1}$ in May to $936 \mathrm{ng} \mathrm{L}^{-1}$ in October. The content of $\Sigma$ OCPs in underground sediments ranged from $51 \mathrm{ng} \mathrm{g}^{-1}$ in January to $3,842 \mathrm{ng} \mathrm{g}^{-1}$ in May. The concentrations of $\Sigma$ OCPs in surface farmland waters ranged from $31 \mathrm{ng} \mathrm{L}^{-1}$ in September to 5,639 $\mathrm{ng} \mathrm{L}^{-1}$ in May, while the surface farmland sediments and soils showed the variations from $11 \mathrm{ng} \mathrm{g}^{-1}$ in October to $3,469 \mathrm{ng} \mathrm{g}^{-1}$ in April and $99 \mathrm{ng} \mathrm{g}^{-1}$ in September to $6,181 \mathrm{ng} \mathrm{g}^{-1}$ in February, respectively. Sinkholes and wells showed the variations in waters from $39 \mathrm{ng} \mathrm{L}^{-1}$ in April to $3,492 \mathrm{ng} \mathrm{L}^{-1}$ in January. The seasonal variations in OCPs found in the underground river suggest that the underground river system was affected by the surface system substantially.

Sources estimation of OCPs in the underground river and surface systems

Different ratios in OCPs are shown in Table 2. The ratios of $\alpha / \beta$ and $\alpha / \gamma$ in newly input commercial $\mathrm{HCH}$ correspond to the ranges of 6-12 and 5-6, respectively while in lindane $\alpha / \gamma$ is 0.01 (Jiang et al. 2009a; Muhayimana et al. 2009). The $\alpha / \gamma \mathrm{HCH}$ and $\alpha / \beta \mathrm{HCH}$ ratios were higher than 0.01 in waters, sediments in the underground river and in sediments, waters, and soils of the surface systems (Fig. 2a-c). The ratios indicate that $\mathrm{HCH}$ in groundwaters, sediments, surface waters, surface sediments, and soils were derived from commercial $\mathrm{HCH}$.

Dicofol contains 3-7 \% DDT (Wang et al. 2008a, b, c); $o, p^{\prime}$-DDT is greater than $p, p^{\prime}$-DDT in dicofol; $o, p^{\prime}$-DDT is lower than $p, p^{\prime}$-DDT in commercial DDT (Qiu et al. 2005); $o, p^{\prime}$-DDT found in major groundwater was not detectable (ND). The concerned $p, p^{\prime}$-DDT was detected. The ratios $o, p^{\prime}$ to $p, p^{\prime}$-DDT were mostly lower than 1 both in two systems, which indicate the source of commercial DDT (Fig. 3a-c).

The ratio of heptachlor to trans-chlordane corresponds to 3.5 in commercial grade heptachlor, while it is 0.5 in commercial grade chlordane (Rostad 1997; Tomlin 1999).

Table 2 Ratios of OCPs in the different samples in the underground and the surface system

\begin{tabular}{|c|c|c|c|c|c|c|c|}
\hline \multirow[t]{2}{*}{ OCPs } & \multicolumn{2}{|c|}{ Underground river system } & \multicolumn{3}{|l|}{ Farmlands } & \multicolumn{2}{|c|}{ Sinkholes and well } \\
\hline & Waters $^{\mathrm{a}}$ & Sediments $^{\mathrm{b}}$ & Waters $^{\mathrm{c}}$ & Sediments $^{\mathrm{d}}$ & Soils ${ }^{\mathrm{e}}$ & Waters ${ }^{\mathrm{a}}$ & Sediments $^{f}$ \\
\hline$\alpha / \beta \mathrm{HCH}$ & $1.4-79.8$ & $0.1-0.7$ & $1.0-207.6$ & $0.2-9.0$ & $0.2-1.0$ & $0.5-204.2$ & $0.3-0.4$ \\
\hline$\alpha / \gamma \mathrm{HCH}$ & $0.9-21.3$ & $0.1-3.0$ & $2.8-49.2$ & $0.4-32.0$ & $0.1-3.0$ & $0.4-76.3$ & $0.3-0.4$ \\
\hline$\Sigma \mathrm{DDT} / \Sigma(\mathrm{DDD}+\mathrm{DDE})$ & $0.2-1.3$ & $0.1-0.4$ & $0.1-2.9$ & $0.1-1.0$ & $0.1-2.3$ & $0.1-8.7$ & $0.1-03$ \\
\hline$o, p^{\prime}-\mathrm{DDT} / p, p^{\prime}-\mathrm{DDT}$ & $0.2-4.7$ & $0.1-0.3$ & $0.1-5.9$ & $0.3-163.8$ & $0.1-0.6$ & $0.1-9.7$ & $0.1-1.4$ \\
\hline$\alpha / \beta$ endosulfan & $0.1-51.0$ & $1.0-210.0$ & $0.1-156.8$ & $0.1-21.8$ & $0.1-2.0$ & $0.1-171.0$ & $0.2-2.8$ \\
\hline Heptachlor epoxide heptachlor & $0.1-1.0$ & $0.1-1178.0$ & $0.1-0.7$ & $0.7-316.0$ & $0.2-2.0$ & $0.1-97.0$ & $0.5-0.6$ \\
\hline Cis/trans-chlordane & $0.1-4.4$ & $0.2-96.5$ & $0.1-14.4$ & $0.1-3.0$ & $0.1-0.5$ & $0.1-14.4$ & $0.1-0.2$ \\
\hline Heptachlor/trans-chlordane & $0.1-1.3$ & $0.3-14.5$ & $0.1-2.4$ & $0.1-10.9$ & $0.2-1.0$ & $0.1-4.2$ & $0.1-0.2$ \\
\hline
\end{tabular}



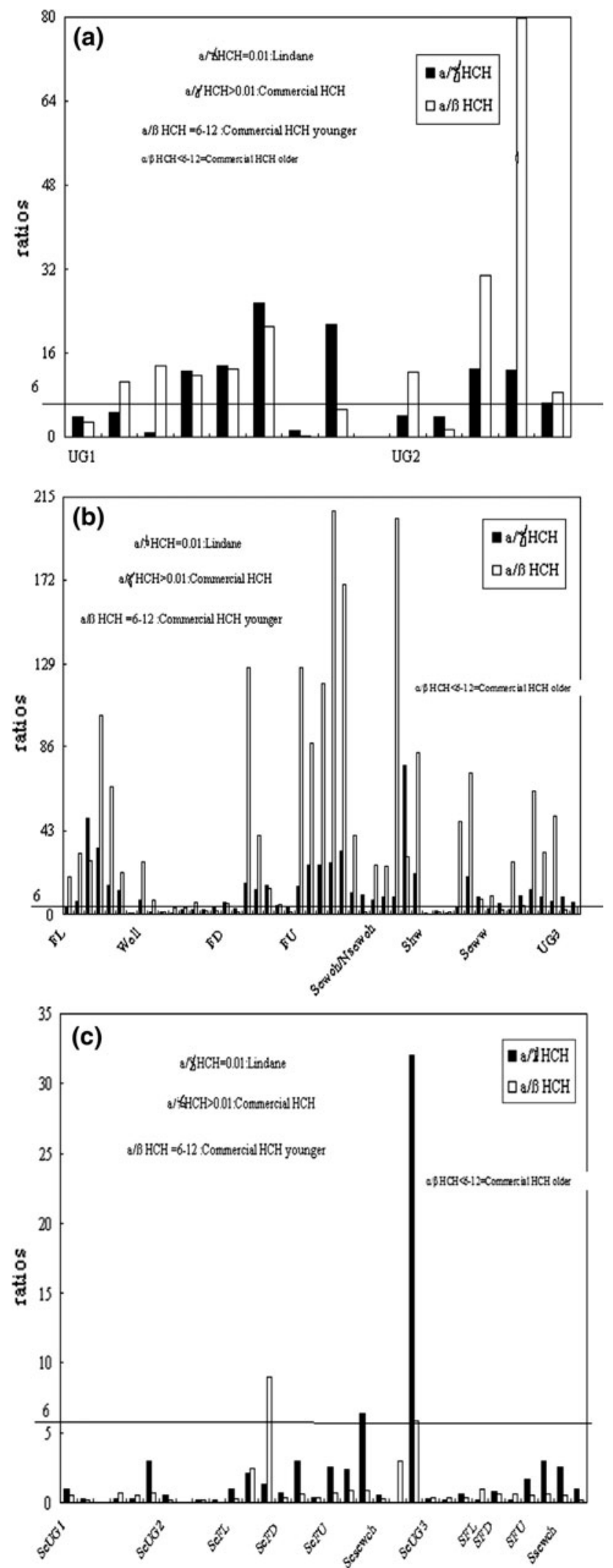

Fig. 2 a $\alpha$ to $\beta$ and $\alpha$ to $\gamma$ ratios of HCH in the waters of the underground river, $\mathbf{b} \alpha$ to $\beta$ and $\alpha$ to $\gamma$ ratios of $\mathrm{HCH}$ in the waters of the surface, $\mathbf{c} \alpha$ to $\beta$ and $\alpha$ to $\gamma$ ratios of $\mathrm{HCH}$ in the sediments and soils of the underground and surface system
The ratios of heptachlor to trans-chlordane in groundwaters and surface waters were around 0.5 . The ratio was around 3.5 at Sewch/Nsewch and Seww (Fig. 4a). These results suggest that heptachlor in groundwaters and surface waters was derived from commercial grade chlordane. Heptachlor was mixed in waters at Sewch/Nsewch and Seww from two sources dominantly from commercial grade chlordane with slight commercial heptachlor. The ratios of heptachlor to trans-chlordane were around 0.5 in surface sediments and soils in the maximum samples (Fig. 4b). These results indicate that heptachlor in sediments and soils was derived from commercial chlordane, also.

The ratio of $\alpha / \beta$ in endosulfan in commercial mixture is 2.33 (Jiang et al. 2009a). Endosulfan in groundwaters, underground sediments, surface waters, surface sediments, and soils might be derived from commercial endosulfan (Fig. 5a, b), because the ratios $\alpha / \beta$ of endosulfan in waters, sediments, and soils were around 2.33.

Commercial chlordane consists of $13 \%$ trans-chlordane, $11 \%$ cis-chlordane, $5 \%$ heptachlor, and other compounds (Wang et al. 2008a, b, c). It was reported that the ratio of cis-chlordane to trans-chlordane in technical chlordane is 0.79 (Dearth and Hites 1991; Rostad 1997). The cis-chlordane to trans-chlordane ratios were around 0.79 dominantly in waters, sediments, and soils both in the underground river and in the surface systems, which indicate that the sources were derived from commercial chlordane in waters, sediments, and soils (Fig. 6a, b). In China, commercial chlordane is still being extensively used as a termiticide with an estimated amount of over 200 tons/ year in recent years (Muhayimana et al. 2009).

Oxychlordane is a metabolite compound of chlordane. Therefore, it is expected that oxychlordane predominantly found in waters, soil, and sediments was derived from trans-chlordane and cis-chlordane in used commercial chlordane.

Heptachlor epoxide is a metabolite of heptachlor. It also was delivered in waters, sediments, and soils from heptachlor.

Aldrin, dieldrin, endrin, and isodrin had never been produced and used in agriculture in China (Jiang et al. 2009a; Muhayimana et al. 2009).

\section{Transport of OCPs in karst systems}

The ratios $\mathrm{HCH}$ of $\alpha / \beta$ and $\alpha / \gamma$ were higher than $6-12$ and 5-6 in the major waters than those in the sediments and the soils. These results indicate that $\mathrm{HCH}$ was mixture of older and younger in the waters while it was older in the sediments and soils. The most likely explanation for the current low concentrations of $\mathrm{HCH}$ in soils and sediments but higher concentrations in waters due to the differences in the physicochemical and biochemical properties, wherein 

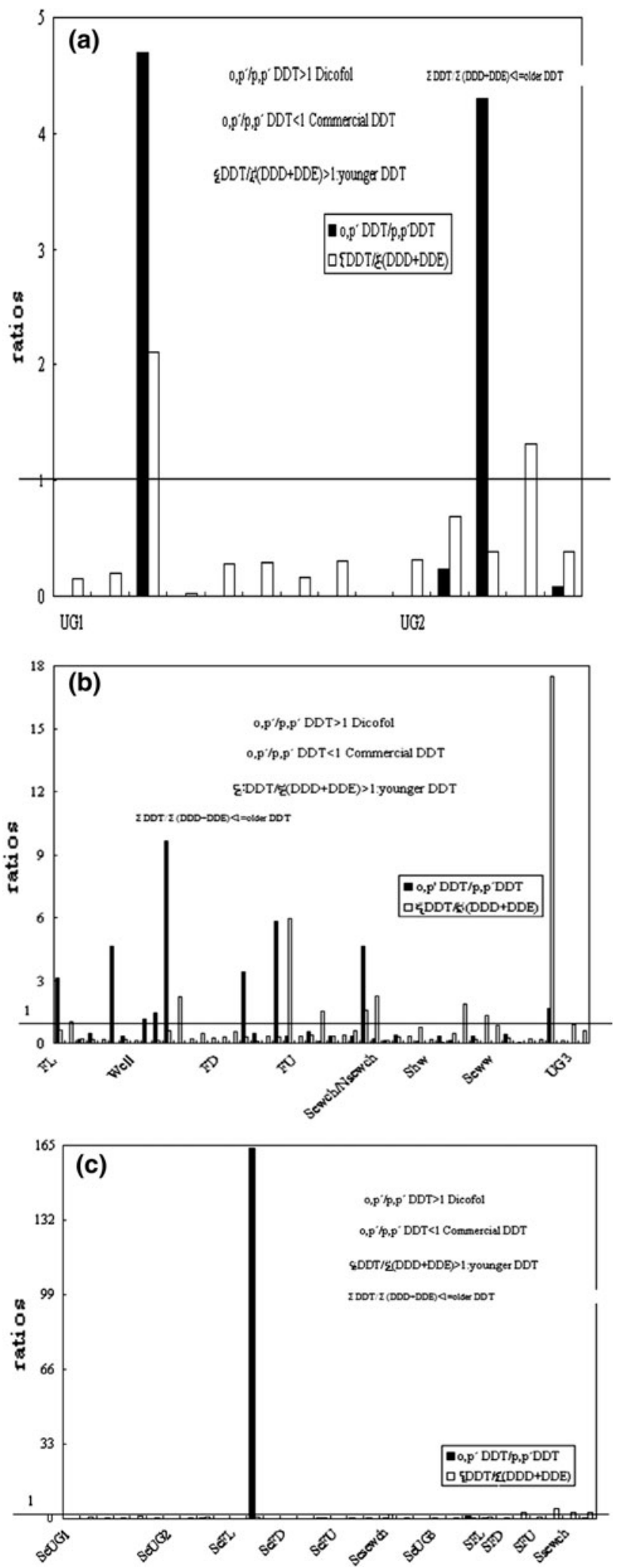

Fig. 3 a $o, p^{\prime} / p, p^{\prime}$-DDT and $\Sigma \mathrm{DDT} / \Sigma(\mathrm{DDD}+\mathrm{DDE})$ in the waters of the underground river, $\mathbf{b} o, p^{\prime} / p, p^{\prime}$-DDT and $\Sigma \mathrm{DDT} / \Sigma(\mathrm{DDD}+\mathrm{DDE})$ in the waters of the surface, $c o, p^{\prime} / p, p^{\prime}$-DDT and $\Sigma$ DDT $/ \Sigma(\mathrm{DDD}+\mathrm{DDE})$ in the sediments and soils of the underground river and surface system
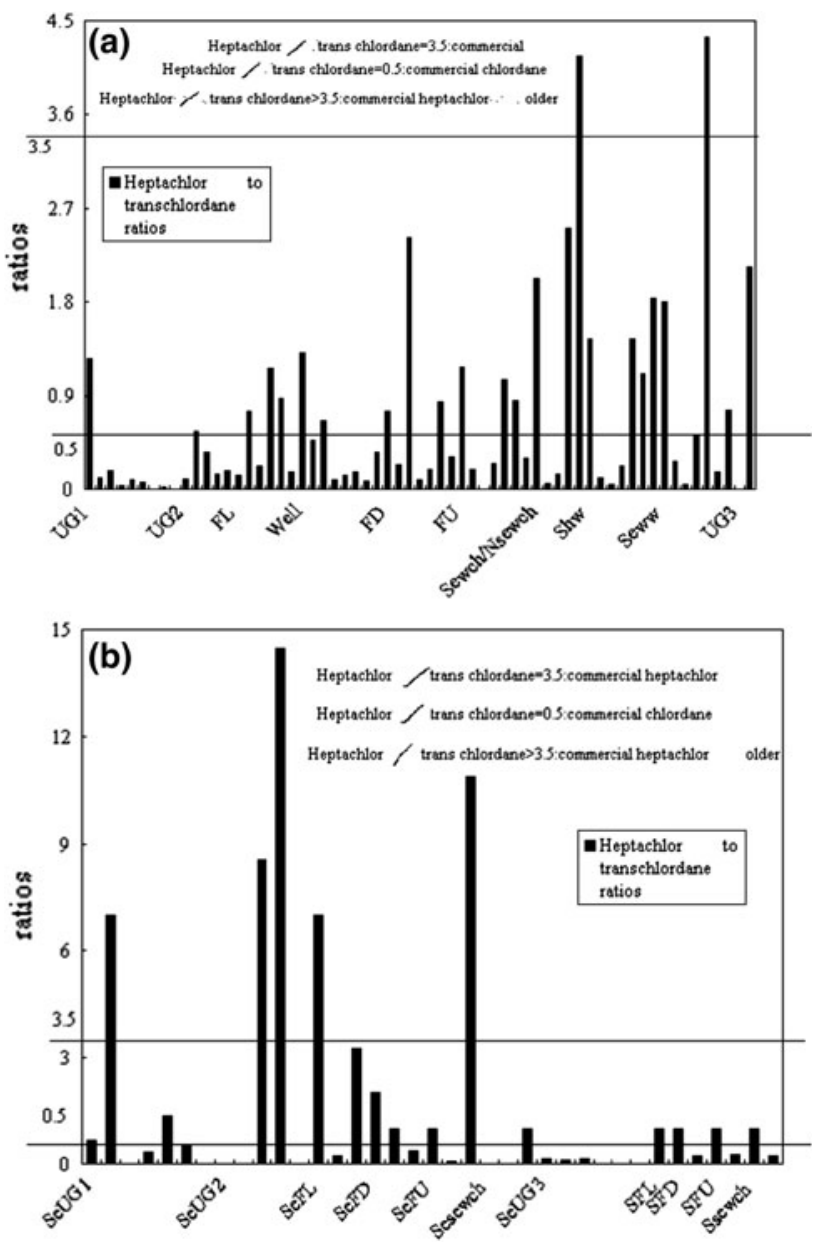

Fig. 4 a Heptachlor to trans-chlordane ratios in the waters of the underground river and surface, $\mathbf{b}$ heptachlor to trans-chlordane ratios in the sediments and soils of the underground river and surface

HCHs have higher water solubility, vapor pressure and biodegradability, and lower lipophilicity and particle affinity as compared to the DDTs (Muhayimana et al. 2009). In addition, higher ratios of $\alpha / \gamma$ and $\alpha / \beta$ in $\mathrm{HCH}$ could be explained by long-range transport or recycling of $\alpha \mathrm{HCH}$, because $\alpha \mathrm{HCH}$ has a longer atmospheric lifetime than $\gamma$ (Willett et al. 1998). Both $\alpha$ and $\gamma$ can be transformed to $\beta \mathrm{HCH}$. Soil carbon can absorb $\beta \mathrm{HCH}$ for a long time and retains in soil and sediment which causes lower the ratio but older $\mathrm{HCH}$ in soils and sediments (Mackay et al. 1997). The $\alpha / \gamma$ and $\alpha / \beta$ ratios in sediments and soils both in the underground river and in surface systems were lower than 5-6 and 6-12, which indicate the substantial transformation of $\alpha \mathrm{HCH}$, but atmospheric deposition of $\alpha$ $\mathrm{HCH}$. Surface systems might have transported older $\mathrm{HCH}$ in the underground system.

DDT can be biodegraded to DDE and DDD (Luo et al. 2004). Then, the ratio of DDT to (DDD + DDE) will be reduced to less than 1 if DDT is not newly added. There- 

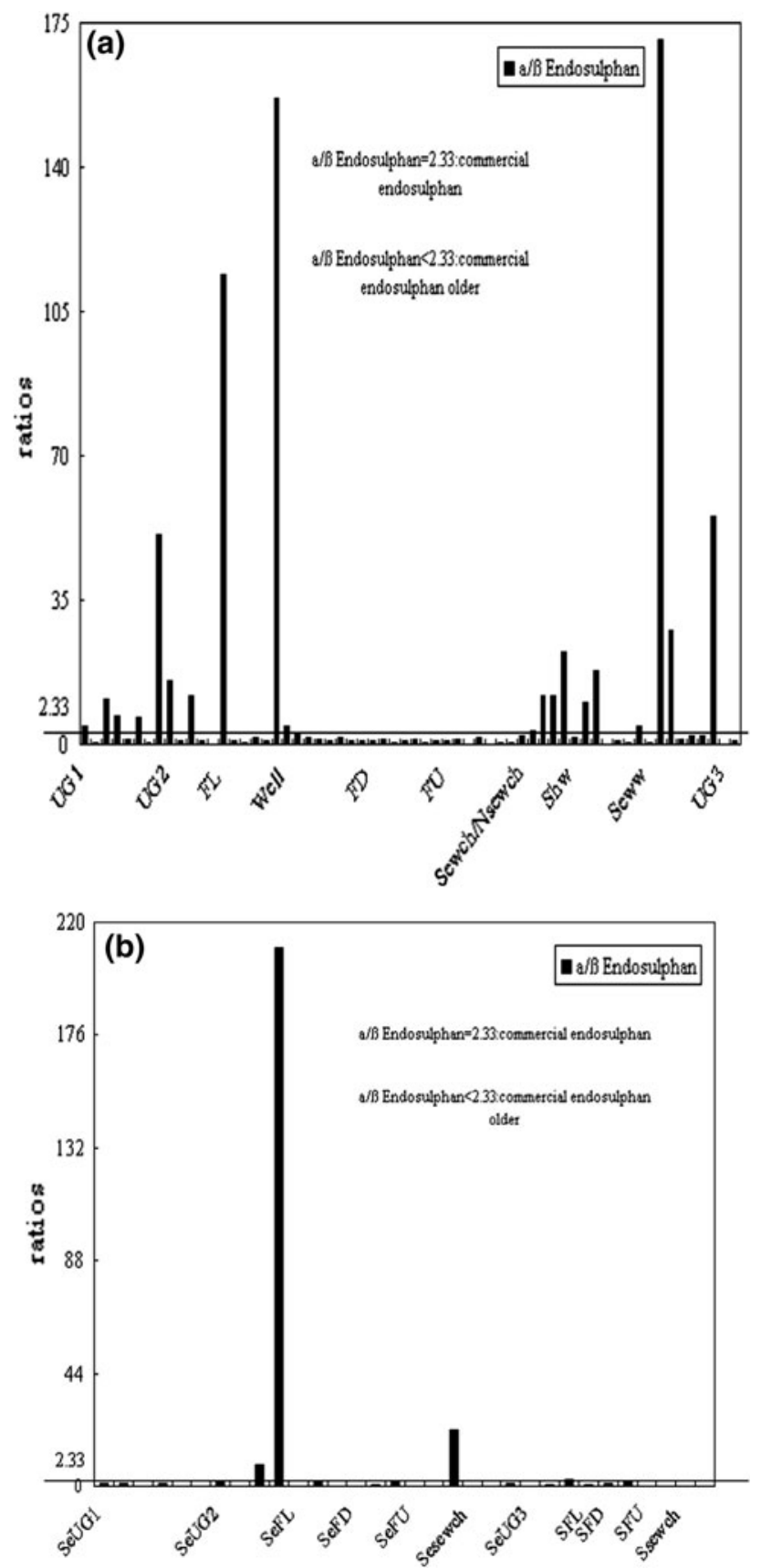

Fig. 5 a $\alpha$ to $\beta$ endosulfan ratios in the waters of the underground and surface system, $\mathbf{b} \alpha$ to $\beta$ endosulfan ratios in the sediments and soils of the underground and surface system

fore, the ratio could be used to distinguish the newer or older sources of DDT. The ratios of DDT to (DDD + DDE) were in lower values dominantly than 1 in water, sediments, and soils both in the underground river and in surface systems (Fig. 3a, b). These results indicate the older DDT was input in two systems. The higher concentrations of DDD and DDE were observed in soils and sediments than those in waters likely to be lower solubility of DDTs and metabolites DDD, DDE tends to
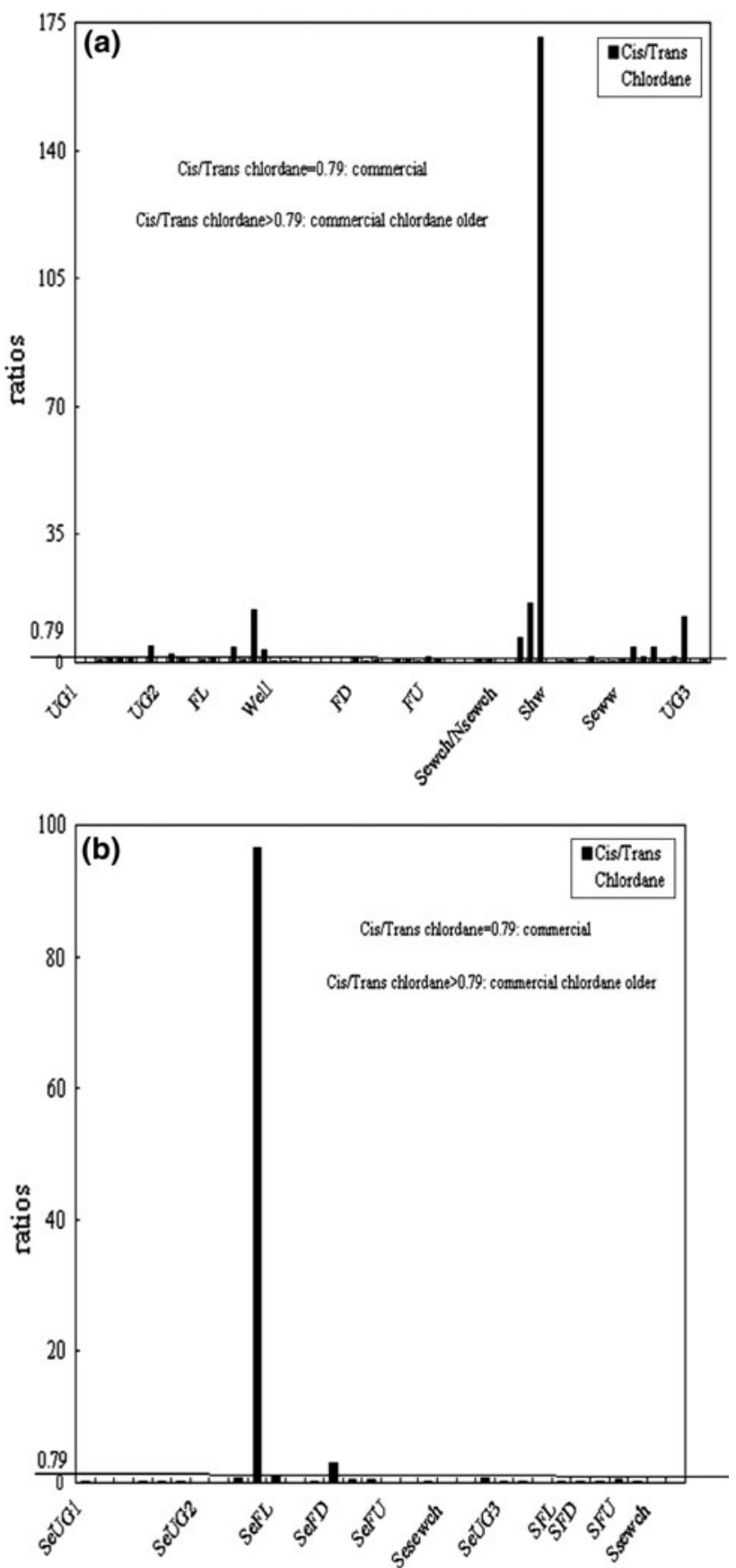

Fig. 6 a Cis-chlordane to trans-chlordane ratios in the waters of the underground and surface system, b cis-chlordane to trans-chlordane ratios in the sediments and soils of the underground and surface system

remain in the particulate phase longer than $\mathrm{HCHs}(\mathrm{Mu}-$ hayimana et al. 2009).

Trans-chlordane can decompose to cis-chlordane, which could cause an increased ratio of heptachlor to transchlordane than 3.5 and 0.5 (Jiang et al. 2009a). Heptachlor to trans-chlordane ratios were lower in sediments and soils both in the two systems, probably the oxidation of 
Fig. 7 Transport of OCPs and karst role

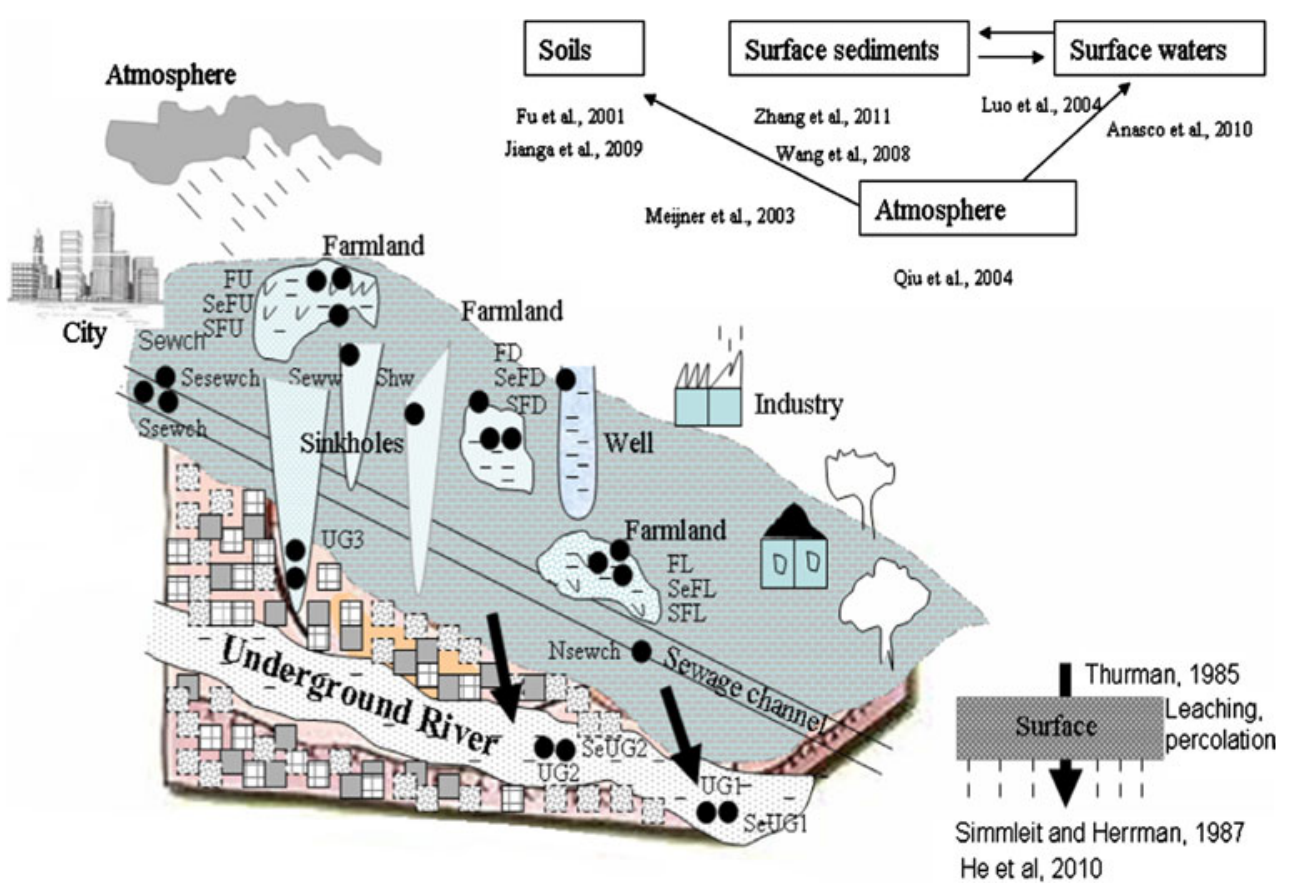

heptachlor to heptachlor epoxide, because much of heptachlor epoxide was found in the sediments and soils (Table 1; Fig. 4b). The higher ratios of heptachlor to transchlordane than 0.5 were dominantly found in surface waters, while in groundwaters were dominantly lower than 0.5 (Fig. 4a). These results indicate that adequate amount of atmospheric deposition of heptachlor or transformation of trans-chlordane to cis-chlordane as well as oxychlordane. Surface systems probably transported the older heptachlor in the underground river system.

$\alpha$ endosulfan decomposes easily than $\beta$ endosulfan and the ratio $\alpha / \beta$ endosulfan then becomes reduced than 2.33 (Jiang et al. 2009a). The reduced ratio can be used as an indicator of older sources. The ratios of $\alpha / \beta$ endosulfans were dominantly in higher values in waters at UG1, UG2, Sewch, Shw, Seww, FL and well than 2.33 (Fig. 5a). These results indicate that recently used commercial endosulfans were input with older endosulfans in groundwaters and surface waters; however, there was a substantial possibility of atmospheric deposition of $\alpha$ endosulfan in waters in surface system. The lower ratios than 2.33 were found dominantly in sediments and soils probably due to the decomposition of $\alpha$ endosulfan (Fig. 5b).

Trans-chlordane is easier to degrade than cis-chlordane (Nomeir and Hajjar 1987). The degradations of transchlordane to cis-chlordane can exceed the reported ratio 0.79. Therefore, the higher ratio than 0.79 could infer between older and newer chlordane (Jiang et al. 2009a). Cis-chlordane/trans-chlordane ratios found in waters, sediments, and soils were lower than 0.79 , which indicate that chlordanes were delivered predominantly from older sources of commercial chlordanes due to the decomposition of cis-chlordane to oxychlordane (Fig. 6a, b). Much of oxychlordane was found in the sediments and soils (Table 1).

OCPs could be transported from the surface into the underground river by leaching and percolation. Leaching of organic materials is a common phenomenon in surface systems (Thurman 1985). Seepage waters and drip waters commonly found in the underground cave are evidence of the introduction of surface waters into the underground river (Simmleit and Hermann 1987; Schwarz et al. 2011). Many fissures found in karst areas can enhance the transport of sediments and soils into underground river by percolation processes (Fig. 7).

Eventually, the seasonal variations found in surface systems ranged from $31 \mathrm{ng} \mathrm{L}^{-1}-5,639 \mathrm{ng} \mathrm{L}^{-1}$ in waters, 11 $\mathrm{ng} \mathrm{g}^{-1}-3,469 \mathrm{ng} \mathrm{g}^{-1}$ in sediments, $99 \mathrm{ng} \mathrm{g}^{-1}-6,181 \mathrm{ng} \mathrm{g}^{-1}$ in soils, and $39 \mathrm{ng} \mathrm{g}^{-1}-3,492 \mathrm{ng} \mathrm{g}^{-1}$ in sinkholes waters might affect the transport $61 \mathrm{ng} \mathrm{L}^{-1}-936 \mathrm{ng} \mathrm{L}^{-1}$ in waters with $10 \%$ and $51 \mathrm{ng} \mathrm{g}^{-1}-3,842 \mathrm{ng} \mathrm{g}^{-1}$ with $33 \%$ of OCPs in the underground river systems (Table 1).

\section{Summaries}

Waters and sediment samples were collected for several months from two fixed stations in the karst Nanshan Underground River. Twenty-four OCPs were used to understand the sources and transport of OCPs in karst system. OCPs in the groundwaters were mixture of older and newly used from commercial sources in maximum samples. OCPs in the underground sediments were older from 
commercial sources. The sources of OCPs in the waters and the sediments of the underground river were consistent with those of the surface systems. Similarities in concentrations in different seasons and in sources and in waters, sediments, and soils were found both in the underground system and in surface systems. These results suggest that the historical surface systems play an important role in OCPs transport in the underground river systems and keep the threat of contamination. However, newly used sources are also liable for the pollution in the water samples. It seems that it still had OCPs contamination due to air transfer, water filtration, and other processes. Karst features were liable regarding the transport and contamination.

Acknowledgments This work is financially supported by the National Natural Science Foundation of China (Grant No. 41172331), the Academician Foundation of Chongqing (CSTC, 2010BC7004), and Geological survey project of Ministry of Land and Resources of China (1212011087119).

Open Access This article is distributed under the terms of the Creative Commons Attribution License which permits any use, distribution, and reproduction in any medium, provided the original author(s) and the source are credited.

\section{References}

Anasco N, Uno S, Koyama J, Matsuoka T, Kuwahora N (2010) Assessment of pesticides residues in fresh water areas affected by rice paddy effluents in southern, Japan. Environ Monit Assess 160(1-4):371-383

Bohlke JK (2002) Groundwater recharge and agricultural contamination. Hydrol J 10:153-179

Cao JJ, Gao Y, Huang HB, Huang HY, Mao L, Zhang X et al (2010) Output characteristics of non-point nitrogen from a typical village region in Yangtze Delta under an individual rainfall event. Environ Sci 31(11):2587-2593

Dearth MA, Hites RA (1991) Complete analysis of technical chlordane using negative ionization mass spectrometry. Environ Sci Technol 25(2):245-254

Ekmecki M (2005) Pesticides and nutrient contamination in the Kestel Polje-Kirkgoz karst springs, Southern Turkey. Environ Geol 49:19-29

Ford DC (1993) Environmental change in karst areas. Environ Geol 21(3):107-109

Fu S, Chu SG, Xu XB (2001) Organochlorine pesticides residue in sols from Tibet, China. Bull Environ Contam Toxicol 66:171-177

Galanopoulou S, Vgenopoulos A, Conospoliatis N (2005) DDTs and other chlorinated pesticides and polychlorinated by phenyls pollution in the surface sediments of Keratsini harbour Saronikos gulf, Greece. Mar Pollut Bull 50(5):520-525

Gao Y, Zhu B, Zhou P, Tang JL, Wang T et al (2009) Effects of vegetation cover on phosphorus loss from a hillslope cropland of purple soil under simulated rainfall: a case study in China. Nutria Cycli Agroecosys 85:263-273

Gao Y, Zhu B, Wang T, Wang YF (2012) Seasonal change of nonpoint source pollution-induced bioavailable phosphorus loss: a case study of southwestern China. J Hydrol 420:373-379
Guo F, Yuan D, Qin Z (2010) Groundwater contamination in karst areas of Southwestern China and recommended countermeasures. Acta Casol 39(2):389-399

He QF, Yang PH, Yuan WH, Jiang Y, Pu JB, Yuan D, Kuang YL (2010) The use of nitrate, bacteria and fluorescent tracers to characterize groundwater recharge and contamination in a karst catchment, Chongqing, China. Hydrogeol J 18:1281-1289

$\mathrm{Hu}$ LM, Zhang G, Zheng BH, Qin YW, Lin T, Guo ZG (2009) Occurrence and distribution of organochlorine pesticides (OCPs) in surface sediments of the Bohai Sea, China. Chemosphere 77:663-672

Hu Y, Qi S, Zang J, Lingzhi T, Jiaquan Z, Yinghui W, Daoxian Y (2011) Assessment of organochlorinated pesticides contamination in underground rivers in Chongqing, Southwest China. J Geochem Explor 11(1-2):47-55

Jiang Y, Wu Y, Groves C, Yuan D, Kambesis P (2009a) Natural and anthropogenic factors affecting the groundwater quality in the Nandong karst underground river system in Yunnan, China. J Contam Hydrol 109:49-61

Jiang YF, Wang XT, Jia Y, Wang F, Wu MH, Sheng GY, Fu JM (2009b) Occurrence, distribution, and possible sources of organochlorine pesticides in agricultural soil of Shanghai, China. J Hazard Mat 170(2-3):989-997

Kihampa C, Mato RR, Mohammad H (2010) Residues of organochlorinated pesticides in soil from Tomato fields, Ngare Nanyuki, Tanzania. J Appl Sci Environ Manag 14(3):37-40

Klánová J, Matykiewiczová N, Mácka Z, Prosek P, Láska K, Klán P (2008) Persistent organic pollutants in soils and sediments from James Ross Island, Antarctica. Environ Pollut 152:416-423

Lan J, He Q, Hu N, Wang P, Ren K, Chen X (2013) Effects of anthropogenic on karst ground water geohydrochemistry in an urbanized area. Adv Mat Reach 726-731:2418-2423

LeGrand HE (1984) Environmental problems in karst terrains. In: Burger A, Dubertret L (eds) Hydrogeology of karstic terrains. IAH, International Contribution Hydrogeology, Hanover, 1:189-194

Liu LH, Shu LC, Chen XH, Oromo T (2010) The hydrologic function and behavior of the Houzhai underground river basin, Guizhou Province, southwestern China. Hydrogeol J 18:509-518

Luo X, Mai B, Yang Q, Fu J, Sheng G, Wang Z (2004) Poly cyclic aromatic hydrocarbon and organochlorinated pesticides in water column from Pearl River and Macao harbor in the Pearl River, Delta. Mar Pollut Bull 48:1102-1115

Mackay D, Shiu WY, Ma KC (1997) Illustrated handbook of physical-chemical properties of environmental fate of organic chemicals, vol V. Lewis publishers, Boca Raton

Mai BX, Fu JM, Sheng GY, Kang YH, Lin Z, Zhang G, Min YS, Zang Eddy Y (2002) Chlorinated and Polycyclic aromatic hydrocarbons in riverine and estuarine sediments from the Pearl River Delta, China. Environ Pollut 117(3):457-478

Meijer SN, Shoeib M, Jantunen LMM (2003) Air-soil exchange of organo chlorine pesticides in agricultural soils. Field measurements using a novel in situ sampling device. Environ Sci Technol 37:1292-1299

Muhayimana AS, Shihua Q, Yinghui W, Xiangsheng K, Owago OJ, Junpeng Z (2009) Distribution and sources of organochlorine pesticides in karst cave, Guilin, China. J Am Sci 5(1):35-43

Mukherjee I, Gopal M (2002) Organochlorine insecticide residues in drinking and ground water in and around Delhi. Environ Monit Assess 76:185-193

Naik PK, Tambe JA, Dehury BN, Tiwari AN (2008) Impact of urbanization on the groundwater regime in a fast growing city in central India. Environ Monit Assess 146:339-373

Nakata H, Kawazoe M, Arizono K (2002) Organochlorine pesticides and polychlorinated biphenyl residues in foodstuffs and human 
tissues from China; status of contamination, historical trend, and human dietary exposure. Arch Environ Contam Toxicol 43:473-480

Nomeir AA, Hajjar NP (1987) Metabolism of chlordane in mammals. Rev Environ Contam Toxicol 100:1-22

Prohic E (1989) Pollution assessment in carbonate terrains. In: Hydrology of limestone terrains: annotated bibliography of carbonate rock. International Contribution Hydrogeology, pp 250-253

Qiu X, Zhu T, Li J, Pan H, Li Q, Miao G, Gong J (2004) Organochlorine pesticides in the air around the Tihu Lake, China. Environ Sci Technol 38:1368-1374

Qiu X, Zhu T, Yao B, Hu J, Hu S (2005) Contribution of dicofol to the current DDT pollution in China. Environ Sci Technol 39:4385-4390

Rostad CE (1997) Concentration and transport of chlordane and nonachlor associated with suspended sediment in the Mississippi River, May 1988 to June 1990. Arch Environ Contam Toxicol 33:369-377

Schwarz K, Gocht T, Grathwohl P (2011) Transport of polycyclic aromatic hydrocarbons in highly vulnerable karst systems. Environ Pollut 159(1):133-139

Simmleit N, Hermann R (1987) The behavior of hydrophobic organic micro pollutants in different karst water systems. Water Air Soil Pollut 34(1):79-109

Tanabe S (1991) Fate of toxic-chemicals in the tropics. Mar Pollut Bull 22:259-260

Tang ZW, Yang ZF, Shen ZY, Niu JF, Cai YP (2008) Residues of organochlorine pesticides in water and suspended particulate matter from the Yangtze River catchment of Wuhan, China. Environ Monit Assess 137:427-439

Thurman EM (1985) Organic geochemistry of natural waters, Martinus Nijholf/Dr. W. Junk Publishers, USA
Tomlin CDS (1999) The e-Pesticide manual: a world compendium, 11th edn., Version 1.1, Farnham, British Crop Protection Council

USEPA (2000) Persistent bioaccumulation and toxic chemicals program

Vidal M, Melgar J, Opez AL, Santoalla MC (2000) Spatial and temporal hydrochemical changes in groundwater under the contaminating effects of fertilizers and waste water. J Environ Manag 60:215-225

Wang F, Jiang X, Bian YR (2008a) Organochlorine pesticides in soils under different land usage in the Taihu Lake region, China. J Environ Sci 19:584-590

Wang Z, Yan W, Chi J, Zhang G (2008b) Spatial and vertical distribution of organochlorine pesticides in sediments from Daya Bay, South China. Mar Pollut Bull 56:1578-1585

Wang XF, Li XH, Cheng HX (2008c) Organochlorine pesticides in particulate matter of Beijing, China. J Hazard Mat 150:350-357

Wang Y, Guo S, Xue R, Qi S, Xu Y, Xue B (2011) Organochlorine pesticides in the soil of a karst Cave in Guilin, China. Environ Monit Assess 180(1-4):489-500

Willett KL, Ulrich EM, Hites SA (1998) Differential toxicity and environmental fates of hexachloro cyclo hexane isomers. Environ Sci Technol 32(15):2197-2207

Zhang H, Cao F, Fang S, Wang G, Zhang H, Cao Z (2005) Effects of agricultural production on phosphorus losses from paddy soils: a case study in the Taihu Lake Region of China. Wet Ecol Manag 13:25-33

Zhang J, Qi S, Xing X, Tan L, Gong X, Zhang Y, Zheng J (2011) Organochlorinated pesticides in soils and sediments, Southwest China: a case study in Xinghua, Bay. Mar Pollut Bull 62(60):1270-1275

Zhu B, Wang T, You X, Gao MR (2008) Nutrient release from weathering of purplish rocks in the Sichuan Basin, China. Pedosphere 18(2):257-264 